\section{3 \\ CLINICAL MANIFESTATIONS OF PATIENTS WITH PANDAS IN PATIENTS FOLLOWED UP AT SREBRNJAK CHILDREN'S HOSPITAL IN 5-YEAR PERIOD}

Matilda Kovac Sizgoric*, M Kovac Sizgoric, A Miculinic, R Gjergja Juraski, L Tambic Bukovac, D Erceg, D Plavec, B Nogalo, G Tesovic, M Turkalj. Srebrnjak Children's Hospital

10.1136/archdischild-2021-europaediatrics.403

PANDAS, or pediactric autoimmune neuropsychiatric disorder associated with Streptococcus pyogenes, is characterized by an acute onset of neuropsychiatric symptoms which seem unexplainable. These symptoms usually include obsessive-compulsive disorder, and a variety of tics, that appear in children before puberty.

The aim of this study was to compare the clinical manifestations of our patients with PANDAS to the latest studies and report our findings.

This retrospectiove study included 20 patients with valid clinical features of PANDAS who were treated and followed at Srebrnjak Children's Hospital between 2014 and 2019.

Our examinees were children before puberty which fullfilled the main criterion of early-onset and at least two major criteria - obsessions/compulsions (OCD) and neuromotor dysfunction (tics, hyperactivity). We retrospectively analized all the data with special focus on neuropsychiatric symptoms.

In 5 -year period a total of 20 children, $16(80 \%)$ male and 4 (20\%) female, aged 3 to 11 years (median age 6,5) were followed up under the diagnosis of PANDAS. Only one patient had a burdened perinatal history (prematurity, shortterm mechanical ventilation, neuromotor habilitation). Family history of tics and autoimmune disorders was positive in $\mathrm{N}=5$ (25\%). All patients had OCD and tics with acute onset of symptoms.

Elevated levels of antistreptolysin titers were found in all but one patient (95\%). Anti-DNAse-B levels were tested in 7 patients and was elevated in 4 (57\%).

Attention disordes were present in $\mathrm{N}=17$ (85\%) and 4 (20\%) patients had sleeping difficulties. Speech difficulties were detected in $\mathrm{N}=5$ (25\%).

Decline in school performance was also commun in children attending school $\mathrm{N}=10$ (71\%).

None of the patients had pathological changes in EEG, and those with neuroimaging studies $(\mathrm{N}=12$ or $60 \%)$ did not have any speciffic findings.

First-line antibiotics were given to 15 (75\%) patients. In 5 $(25 \%)$ patients a full regression of symptoms was registered, $10(50 \%)$ had partial improvement, $5(25 \%)$ had no response. In 7 (35\%) patients intravenous immunoglobulins (IVIG) were given after initial antibiotic treatment with incomplete regression. Tics persisted in 11 patients and 4 had tics with behavioral difficulties. In 7 patients treated with IVIG we proceeded with parenteral antibiotics because of partial symptom regression and 2 were given corticosteroids (still followed).

We observed a higher rate of full symptom regression with first-line parenteral antibiotics and some of them improved after IVIG. Further research on larger cohorts of patients are necessary for better management of this clinical entity.

\section{PATTERNS OF INTERNET USE BY RUSSIAN SCHOOLCHILDREN}

Tinatin Gogberashvili*, G Karkashadze, T Konstantinidi, D Bushueva, E Kaytukova. Central clinical hospital of the Russian academy sciences

10.1136/archdischild-2021-europaediatrics.404

Study the amount of internet use by Russian schoolchildren and its connection to the other factors of social functioning.

Schoolchildren from 9th grade from 5 major cities in Russia participated in the research. The questionnaire concerning out-of-school life and well-being was used. The questionnaire was filled in by the parents.

A total of 598 children were examined, with an average age of 14,83 years, $48,7 \%$ of them being girls.

It was found that during the schooldays $26 \%$ of the children do not use the internet at all, 16\% - spend less than an hour a day; 20\% - spend around 1-2 hours a day on the internet; $15 \%$ - 2-3 hours a day; 23\% - 3-4 hours a day. A direct connection was revealed between internet use and interest in computer games $(r=0,95)$.

Clear gender distinction was found: among the children using the internet more than 3 hours a day - 64,1\% were boys. Among the children not using the internet at all or spending less than an hour a day on the internet - 71,8\% were girls.

Children who use the internet a lot (more than 3 hours a day) are more likely to sleep less than the others: less than 8 hours $(50,8 \%$ against $42,6 \%)$. However, there is no significant distinction between those who do not use the internet at all or use the internet 1,2 , or 3 hours a day.

Further, children who use the internet for more than 4 hours a day participate less in sports-related activities and clubs $(25,8 \%$ against $37,9 \%)$. However, there is no significant distinction in terms of the involvement in sports between those who do not use the internet at all or use the internet for 1,2 , or 3 hours a day.

There is a direct connection between internet usage and interest in computer games. Boys spend significantly more time on the internet than girls. This could be explained by the faster development of higher mental functions for girls and less interest in computer games. There are no significant distinctions between the children who use the internet moderately and the children who do not use the internet at all. However, the children who use the internet a lot, sleep reduced hours, and are less interested in sports.

\section{BLOCH-SULZBERGER SYNDROME - A RARE X-LINKED DERMATOSIS}

Yulia Nesterova*, Natalia Sergienko, Georgii Karkashadze, Leila Namazova-Baranova. The Research Institute of Pediatrics and Child Health of the Central Clinical Hospital of the Russian Academy of Sciences of the Ministry of Science and Higher Education of the Russian Federation

\subsection{6/archdischild-2021-europaediatrics.405}

Bloch-Sulzberger syndrome is a rare genetically determined dermatosis, manifested by skin changes in combination with 